\title{
School space selection preferences: Architectural perspective toward formal school
}

\author{
Kurnia Widiastuti ${ }^{1}$, Mohamad Joko Susilo ${ }^{2}$, Hanifah Sausan Nurfinaputri ${ }^{3}$ \\ ${ }^{1}$ Department of Architecture and Planning, Engineering Faculty, Gajah Mada University, Indonesia \\ ${ }^{2}$ Master of Islamic Studies Department, Universitas Islam Indonesia, Indonesia \\ ${ }^{3}$ Graduate Student of Architecture and Planning Department, Engineering Faculty, Gajah Mada University, Indonesia
}

\begin{tabular}{l} 
Article Info \\
\hline Article history: \\
Received Aug 8, 2020 \\
Revised Feb 9, 2021 \\
Accepted Apr 10, 2021 \\
\hline
\end{tabular}

\section{Keywords:}

Architecture

Formal school

Preferences

School space

\begin{abstract}
School space plays an essential role in creating a pleasurable learning atmosphere. The tendency of everyone to choose a school space also varies. By knowing this trend pattern, schools can be designed to improve student learning effectiveness. The purpose of this study was to find out which school spaces students choose to study, what kind of room criteria are needed, and distribution patterns of students' preference choices. This research used both the qualitative exploratory and quantitative methods using an open-ended question questionnaire for data collection. Data analysis techniques used qualitative analysis methods consisting of open coding, axial coding, and selective coding. The results showed that the library, mosque, and multimedia laboratory were the most preferred space for students to study at school. Some factors that influence the selection include thermal comfort, completeness of supporting facilities, and acoustic comfort.
\end{abstract}

This is an open access article under the CC BY-SA license.

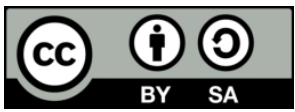

\section{Corresponding Author:}

Kurnia Widiastuti

Department of Architecture and Planning, Engineering Faculty

Gajah Mada University

02 Grafika Road, Senolowo, Sleman, Yogyakarta, 55282, Indonesia

Email: k.widiastuti@ugm.ac.id

\section{INTRODUCTION}

The debate about the figure of a pleasurable school in supporting learning has been highlighted over the years [1]-[4]. Schools that are central to the ongoing learning process are always improving quality to achieve maximum learning outcomes. Teaching and learning activities do not necessarily occur in the schoolroom, but every corner is an object of learning [5]-[8]. Also, the availability of learning vehicles and physical conditions of learning that support needs are essential for creating a comfortable learning atmosphere [9].

School is a building or institution for learning and teaching and a place to receive and give lessons [10]. In consequence, the school needs to adapt to the needs of students. Moreover, the development of the curriculum causes the time spent by students at school to become longer. The current Indonesian government policy increases compulsory education duration, which was initially nine years to 12 years [11]. Improvement efforts the quality of student learning environments continue to be improved to increase enthusiasm and support teaching and learning activities, and improve the school's physical environment quality. This is vital because it will have an impact on various things, such as student performance, student motivation [12], student outcomes [13], student achievement [14], student behavior [15], [16], student mental health [17], [18], and students' interactions [19], [20]. 
Given the many effects of school space on learning, a school needs to meet optimal design standards and physical learning space. In the past, school facilities were made based on the need to accommodate only formal learning, called classrooms and laboratories. Now, every school space can be a place as well as an object of learning [7], [18], [21]. Globally, there are currently many schools, both in Indonesia and in other countries, improving the quality of their learning through reform of traditional classes into more innovative outdoor learning [16], [20], [22]. Creative use of school space (as an outdoor learning tool) is beneficial in various ways, including social-personal development of students, enhancing achievement, inspiring, stimulating students' positive mental growth towards the environment, and involving the more physical activity of students [16], [18], [21], [23].

As defined by the Organization for Economic Cooperation and Development (OECD), school space is a physical learning environment that supports the learning process, both inside and outside school [22]. The school's physical environment, also known as school space, can be classrooms, libraries, halls, canteens, fields, pavilions, mosques, and school grounds. Learning that utilizes school space is known as outdoor learning. In Indonesia, learning uses school space in Muhammadiyah Sapen Elementary School in Yogyakarta, Indonesia, which applies a school framework [16].

According to Granito and Santana [24], space and physical environment conditions will impact the teaching and learning process. Therefore, as a form of concern for schools, the Indonesian government has also set some spatial standards for school environment as listed in Regulation of the Minister of National Education of the Republic of Indonesia [25], which covers: area of land and buildings compared to the number of students, infrastructure (types of space), and facilities adjusted for each level (Elementary School, Junior High School, and Senior High School) to ensure the comfort of students while studying at school.

However, in practice, the current outputs do not always answer the stated goals. The standard of air treatment or lighting facilities in school buildings proclaimed by the government is still limited to subjective assessment, determined by a simple "sufficient" or "adequate," and then interpreted very diverse by the schools. Based on the author's observation at Salsabila Primary School of Banguntapan and several other elementary schools in Yogyakarta in 2013-2017, while assisting the planning of elementary school buildings established on limited land, the school owners' awareness of the importance of classroom conditions and lighting is relatively low. Muhammadiyah schools, the research scope, were generally built before the era of rapid advancement in information technology. Renovation and building addition due to significant progress in the curriculum was improperly planned and tended to cause new issues affected by the school complex's high-density density. Therefore, it is essential to formulate a more specific learning space design and be applied in schools, especially in Indonesia. On this basis, researchers intend to express patterns of student tendencies in choosing a comfortable place to study.

Previous research has also found factors that tend to be students' preference for learning space in schools. A study conducted by Harrop and Turpin [26] states that there are nine attributes of learning space preference, including: 1) Destination, related to the selection of students' places to study; 2) Identity, concerning the feel and impression of the room they are using; 3) Conversation, regarding the adequacy or absence of space as a vehicle for collaboration and interpersonal communication; 4) Community, regarding social interaction, support, and one goal; 5) Security, regarding the protection of privacy or safeguarding of individuals; 6) Time, concerning the availability of space by the level of user needs; 7) Human factors; 8) Physical condition, concerning the physical condition of study room such as lighting and acoustics; and 9) Resources, the availability of learning support components, and refreshments (such as food, drinks).

Similar research has also been carried out by Damşa, et al. [27] concerning the study of learning space from an ecological perspective. This study's contribution is that to support learning space is needed: enrichment of learning resources and a conducive learning atmosphere, appropriate learning context. Also, management of learning implementation must produce the necessary flexibility and permeability to access large-scale ecology from available sources. Granito and Santana [24] discusses students' and teachers' perspectives on classrooms and the environment that influences the learning process from a psychological perspective. The results showed that three main variables: 1) Conditions, representing all problems in the room such as space, temperature, and light; 2) Results, including several variables, such as concentration, involvement, and student grades; and 3) Value, including the extent of the impact of learning in the classroom.

The difference between this research and existing research lies in the level of school used, location, research object, point of view of the study, and the complexity of the method used. This research's similarity with existing research is in educational research facilities that support learning space and type of analysis used.

This study aimed to determine which school spaces students choose to study, criteria for what school space students need, and distribution patterns of these preferences. The selection of research respondents were students from the Muhammadiyah school foundation at the elementary, junior high school, and senior high schools in selected schools in Yogyakarta, Indonesia. The criteria for the space needed to 
create a place that supports student learning activities will reveal through the respondent's answers. This research result suggests designing a school or learning space that is fun and supports learning objectives.

\section{RESEARCH METHOD}

This study employed qualitative and quantitative methods [28] with exploratory research categories [29] to find out information about the reasons for choosing learning space and school space criteria as what students need to learn. The data collection method uses an open-ended question questionnaire. Respondents were 772 students from Yogyakarta Muhammadiyah foundation schools at the elementary school level of 245 students, Junior High Schools by 265 students, and Senior High Schools by 262 students. Data analysis techniques using qualitative content analysis methods with three stages: open coding, axial coding, and selective coding [30]. In the open coding stage, respondent's answers, which are text data, are identified to obtain keywords. Later, the axial coding stage will make a category of keywords gathered at the open coding stage. Finally, selective coding established the relationship between categories.

The research used purposive sampling considering that the Muhammadiyah schools in Yogyakarta, Indonesia, were 60 schools scattered in the central, western, and eastern regions of Yogyakarta, Indonesia. Three school samples consisting of elementary school, junior high school, and senior high school represent each area. The total nine school samples are $15 \%$ of the total population (60 Muhammadiyah schools). The value of $r$ count obtains the reliability test results $(0.618)>$ the value of $r$ table $(0.444)$, then the instrument is declared reliable. The results of the validity test item 1-15 are declared valid because the value of $\mathrm{r}$ count Cronbach's Alpha>R table value (0.444).

\section{RESULTS AND DISCUSSION}

Referring to the analysis step about choosing a place of learning based on students' reasons can be explained in three stages.

\subsection{Open coding stage}

This stage aims to determine the keywords of each student's answer related to the question asked to the respondent regarding the most comfortable and comfortable place to study. The students' answers presented are the top 12 answers that often appear, includes a library, mosque (praying room), multimedia laboratory, canteen, schoolyard, hall, laboratory, class, outside the classroom, park/garden, in front of the classroom, and music room. Figure 1 illustrates the percentage of the frequency distribution of respondents' answers.

Based on the results of open coding and axial coding analysis, which produces 1,358 sub-data, there are 20 place-related keywords with 12 keywords that most often appear. Students' three favorite places to study at school are libraries at $45.36 \%$, mosque or mosque at $9.21 \%$, and multimedia laboratories (multimedia rooms, ICT rooms, computer laboratories) at $7.13 \%$. In comparison, the other $37.31 \%$ consisted of very diverse choices, including canteen (5.94\%), schoolyard (5.27\%), hall (4.68\%), and laboratory $(3.97 \%)$ as in Figure 1.

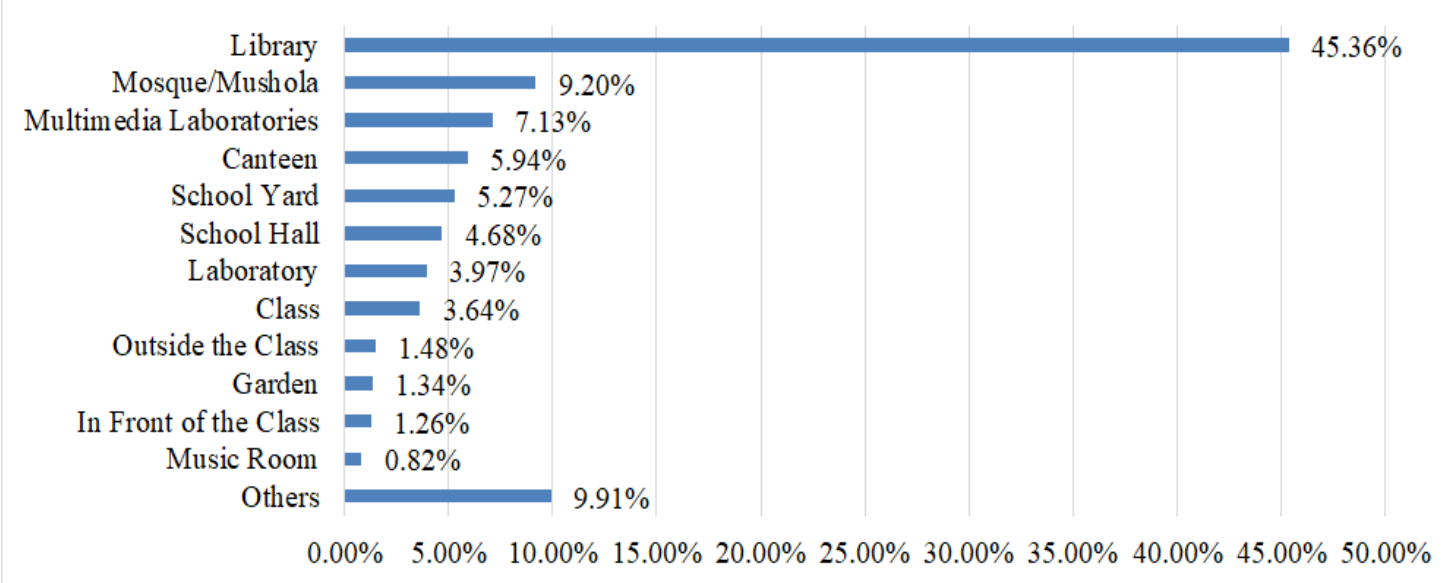

Figure 1. Distribution of places in the school that are comfortable for learning 
Respondents who chose the library reasoned that a library is a comfortable place $(15.5 \%)$, there are many books $(15.2 \%)$, and quietness $(9.2 \%)$. Respondents who chose a mosque reasoned that the mosque was a comfortable place $(19.4 \%)$, cold $(19.4 \%)$, quietness $(8.1 \%)$, and large $(8.1 \%)$. Meanwhile, respondents who chose the multimedia laboratory reasoned that it was air-conditioned (18.8\%), comfortable (17.7\%), cold $(14.6 \%)$, and free Wi-Fi (5.2\%) place. Table 1 presents answers to questions that explain the respondents' arguments in choosing a convenient learning location in the open coding data.

Table 1. Open coding data for reasons students choose school space

\begin{tabular}{|c|c|c|}
\hline Question & Answers & Keywords \\
\hline \multirow{8}{*}{$\begin{array}{l}\text { Reasons to } \\
\text { choose the place: }\end{array}$} & 1. Comfortable and many books that can be read (no. 76) & $\begin{array}{l}\text { Comfortable; Access references sources; } \\
\text { Can read }\end{array}$ \\
\hline & 2. Can monitor the motor (no. 680) & Monitor the motor \\
\hline & 4. Because there are AC and a computer (no. 247) & AC; Computer \\
\hline & 5. Can eat and drink (no. 596) & Can eat; Can drink \\
\hline & 8. Can study seriously and provide question material (no. 766) & Can concentrate; Access reference sources \\
\hline & $\begin{array}{l}\text { 9. The class is cold, neat, not a lot of garbage scattered } \\
\text { (no. 354) }\end{array}$ & Cold; Neat; Clean \\
\hline & $\begin{array}{l}\text { 10. The class is just right, and the location is far from the crowd } \\
\text { (no. 569) }\end{array}$ & Class is correct \\
\hline & $\begin{array}{l}\text { 14. Can play music and make music for a moment to release the } \\
\text { existing stress (no. 391) }\end{array}$ & Music; Cold \\
\hline
\end{tabular}

\subsection{Axial coding stage}

After open coding, category induced using the grouping of keywords (axial coding) of the answers obtained in open coding, questions to the respondent about the reasons for choosing a learning space makes the data. Table 2 presents the categorization of the respondents' motives. Distribution analysis used these categories. There are 13 categories of reasons students choose a place for studying in school. Figure 2 displays the percentage of the frequency distribution of respondents' answers.

Figure 2 shows that the most mentioned room criteria by students in Yogyakarta are the category of "Thermal Comfort" by 38.3\% and "Completeness of Supporting Facilities" by 17.1\%. Other criteria follow with $12.7 \%$ for "Acoustic Comfort" and $10.4 \%$ for "Diversity of Activities," while other spatial measures that are least dominant are the category of "Learning Productivity" by $1.8 \%$, "Visual Quality of the Site and Buildings" by $4.4 \%$, "Safety Control" by $0.1 \%$, "Psychic Comfort" by $5.9 \%$, "Lighting Comfort" by $0.7 \%$, "Freedom of Movement" by 3.5\%, "Proximity of Accessibility" by $0.1 \%$, "Social Interaction" by $0.8 \%$, "Access to Natural Environments" by $1.2 \%$, and last is "Access to Landscape to the Surrounding Environment" by $0.2 \%$.

Table 2. Axial coding data for reasons students choose school space

\begin{tabular}{ll}
\hline \multicolumn{1}{c}{ Keywords } & \multicolumn{1}{c}{ Category } \\
\hline Comfortable; AC; Fresh; Cold & Thermal comfort \\
Access reference sources; Computer & Completeness of supporting facilities \\
Quietness; Quiet & Acoustic comfort \\
Can read; Can eat; Can drink; Music & Diversity of activities \\
Can concentrate; Good & Psychical comfort \\
Neat; Clean & Visual quality of site and building \\
Large; Comprehensive & Freedom of movement \\
Easy to receive lessons & Learning productivity \\
Many trees & Access to the natural environment \\
With friends & Social interactions \\
Bright & Lighting comfort \\
Monitor the motor & Safety control \\
Class is correct & Proximity of accessibility \\
\hline
\end{tabular}




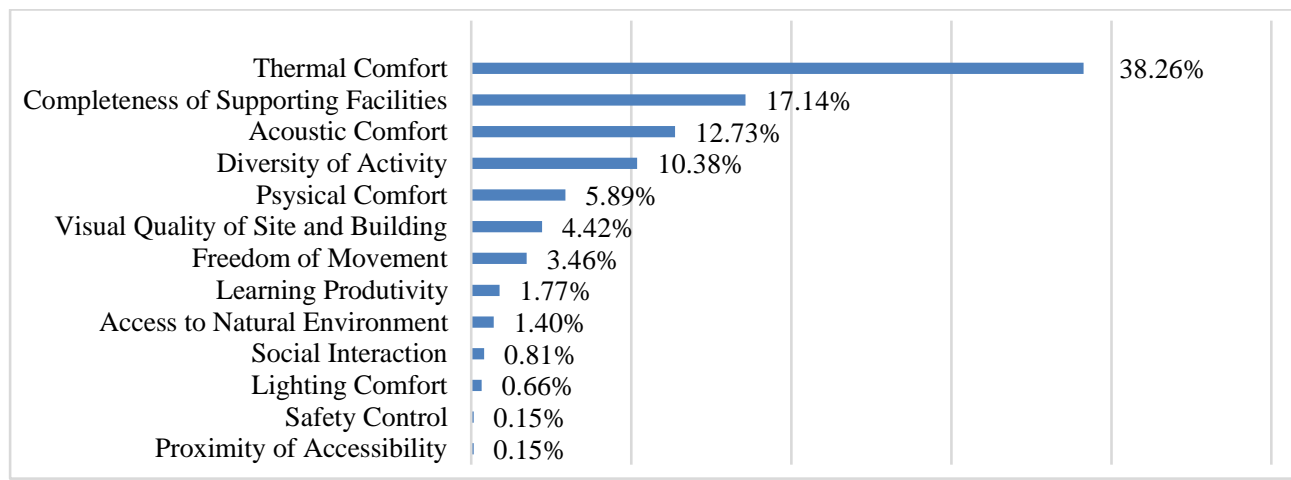

Figure 2. Distribution of reasons for choosing learning space

The students' reasons for choosing a suitable space for studying are on three types, namely gender, education level, and the school location zone.

a. Based on gender

Based on gender, there are no significant differences between male and female respondents. In the first position, the Thermal Comfort preference number reached $40.7 \%$ in male respondents' sub-data and $37 \%$ in female respondents' sub-data. Figures for Supporting Completeness of Support Facilities in the second position reached $14.4 \%$ in male respondent sub-data and $18.6 \%$ in female respondent sub-data. In Acoustic Comfort preference rate, it comes $11.9 \%$ in male respondent sub-data and $13.9 \%$ in female respondent subdata. It's just a sub-data of male respondents showing a slightly greater preference for Activity Diversity $(12.9 \%)$ than Acoustic Comfort a shown in Figure 3.

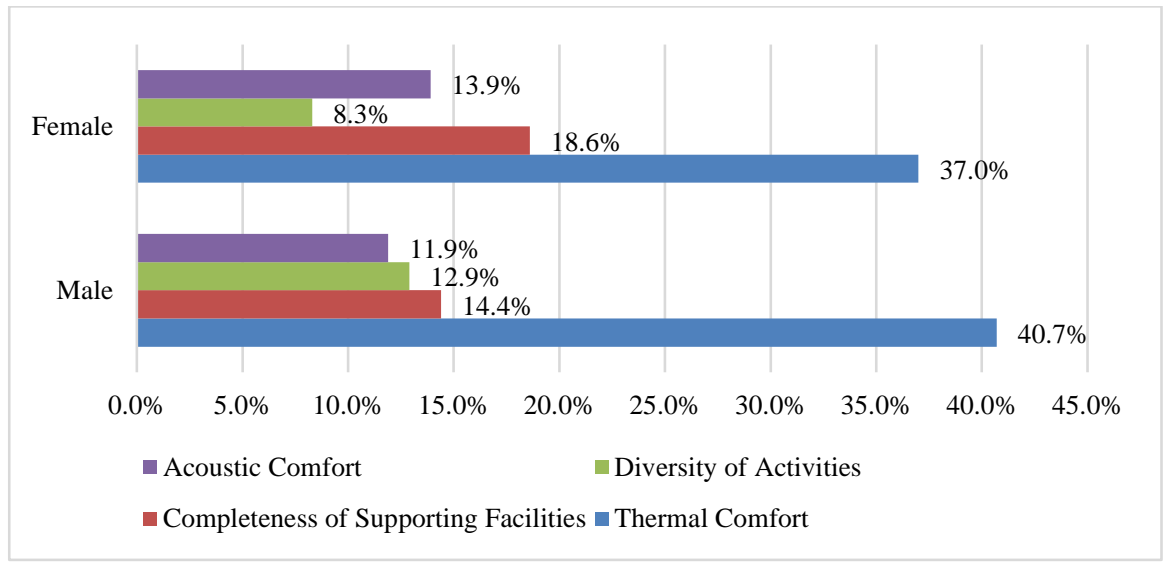

Figure 3. Comparison of reasons for choosing school space based on gender

b. Based on the study level

Figure 2 shows the comparative analysis of distribution reasons for selecting learning spaces between respondents. The diagram illustrates that the respondents at the elementary level do not prioritize thermal comfort $(35.1 \%)$ over respondents at junior high school level (38.2\%) or high school (41.5\%). However, the figure is more dominant than other categories. Elementary School students also showed a more increased need for completeness of supporting facilities $(22.5 \%)$ compared to junior high school students (13.5\%) and high school students (16.2\%). Regarding acoustic comfort, the figure is directly proportional to increasing levels: $8.7 \%$ for elementary students, $13.9 \%$ for junior high school students, and $15.3 \%$ for high school students. Figure 4 concluded that elementary students need more diversity of activities (17.7\%) than junior high school students $(8.4 \%)$ and high school students $(5.7 \%)$. 


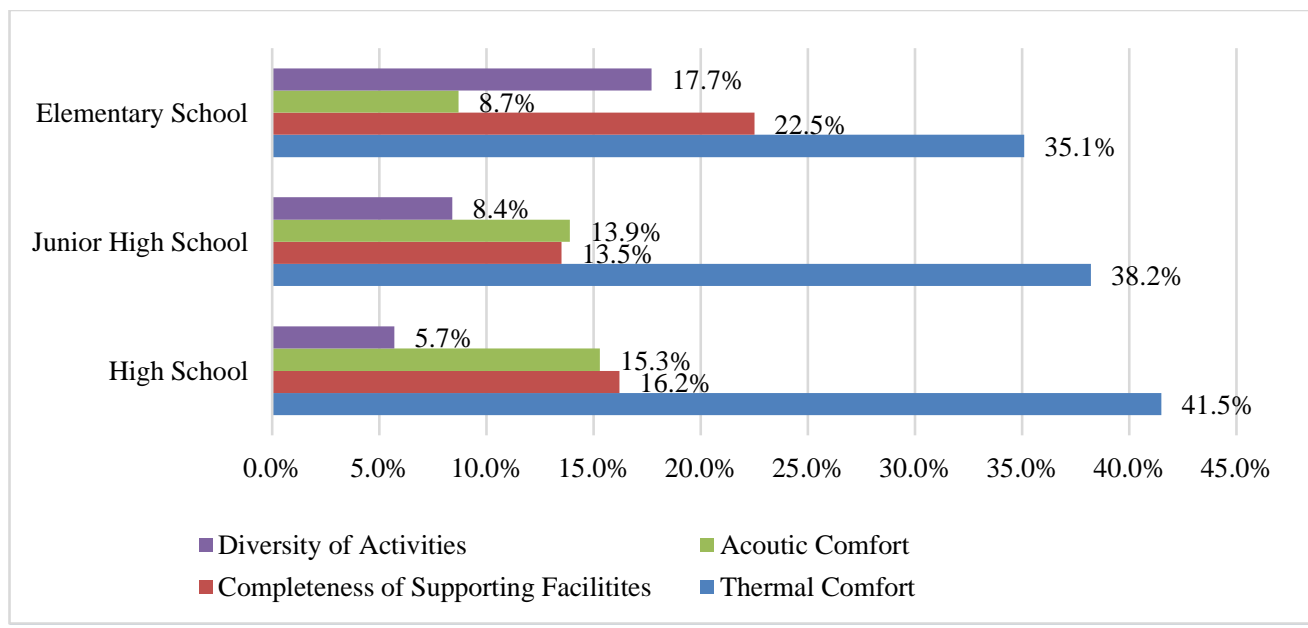

Figure 4. Comparison of reasons for choosing school space based on school level

c. Based on the school location zone

The different reasons for selecting student learning spaces can also be sorted based on the school location zone, as summarized in Figure 5. Figure 5 shows the most dominant reason for students in each region in determining learning space, namely Thermal Comfort, with an average of $38.8 \%$. The highest percentage was obtained from schools originating from the eastern part of Yogyakarta (46.4\%), and then successively following schools from the western region (35.9\%) and the central region (34.2\%). Completeness of Support Facilities with an average of 16.6\%, Acoustic Comfort with an average of 12.7\%, and Diversity of Activities with $10.3 \%$ is the next dominant answers. Safety Control occupied the least answers to the reasons for the selection of space in each area (mean 0.1\%), Proximity of Accessibility (average $0.2 \%$ ), and Lighting Comfort (average 0.7\%).

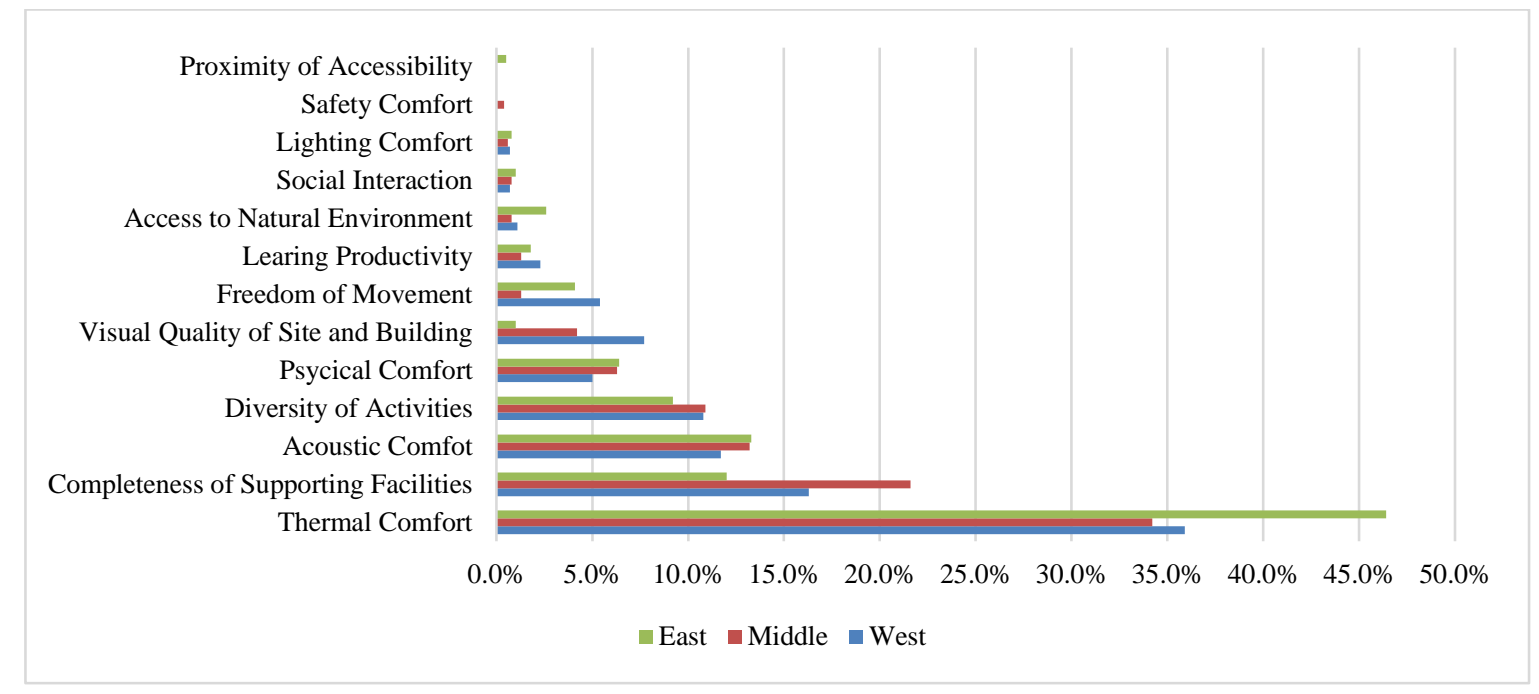

Figure 5. The different reasons for choosing a school space based on the location zone

There is a significant difference in the analysis of reasons for learning spaces selection in the eastern part of Yogyakarta compared with the regions of the western and central area of Yogyakarta, Indonesia, namely the Visual Quality Site and Building category. The reason is $7.7 \%$ and $4.2 \%$ in the central and west part while it only gets $1 \%$ in the east. Meanwhile, sub-data respondents in the central region have a higher preference for completeness of supporting facilities $(21.6 \%)$ than in the eastern part (12\%) or the western region $(16.3 \%)$. As for the freedom of movement, the territory of the west has the highest preference $(5.4 \%)$, followed by the eastern part $(4.1 \%)$, then the central area $(1.3 \%)$. 


\subsection{Selective coding stage}

In this section (selective coding), the 13 categories develop two broad categories of themes, namely "Physical" (57.99\%) and "Non-physical" themes (42.01\%). Table 3 presents the grouping of themes. This exploratory research aims to determine which school spaces students chose to study, the reasons students chose the school space, and the distribution patterns of learning space selection preferences. This study's respondents are Muhammadiyah elementary, junior high school, and senior high school students in several schools in Yogyakarta, Indonesia, were used as respondents in this study. The respondents' answers obtained the space's criteria to create a place supporting student learning activities.

Table 3. Data grouping themes for reasons students choose school space

\begin{tabular}{lc}
\hline \multicolumn{1}{c}{ Category } & Themes \\
\hline $\begin{array}{l}\text { Access to the natural environment; Proximity of accessibility; Freedom of } \\
\text { movement; Completeness of supporting facilities; Acoustic comfort; Lighting } \\
\text { comfort; Thermal comfort; Safety controls; Visual quality site and building }\end{array}$ & Physical \\
Social interaction; Diversity of activities; Psychic comfort; Learning productivity & Non-physical \\
\hline
\end{tabular}

This study result that the most desirable school space for students in elementary, junior high school, and senior high school levels of Muhammadiyah in Yogyakarta are libraries, mosques (praying room), and multimedia laboratories. However, there are also low preferred spaces include canteens, schoolyards, and halls. Reasons for choosing the learning space include thermal comfort, completeness of supporting facilities, acoustic comfort, and diversity of facilities. Other not so prominent reasons include learning productivity, site and building visual quality, safety controls, and psychological comfort.

The library becomes a favorite learning space for students from various backgrounds, elementary, junior high school, senior high school, and college. In the library, it is possible to create an atmosphere of learning and a fun learning process because it has certain conditions that are different than other spaces: abundance and completeness of book collection; availability of learning media (CDs/DVDs, projectors, teaching aids, and other learning media); presences of nuances, such as specific spiritual or educational themes; adequate lighting and air ventilation, well-maintained cleanliness, place neatness, bright-painted walls, and other factors [31]. On the other hand, the library can also be a space that students are less interested in because of its less strategic location, the room's arrangement that lacks art, untidy placement of furniture, dim lighting, dirty rooms, and unpleasant service [32], [33].

The library aims to support the learning process. As stated in article 23 of the Library Law, any library must meet national library standards. A library needs to have several measures such as: a compulsory collection, supporting teaching and learning activities, developing book collections that support student learning processes, serving students with equality services, developing IT (information technology)-based services, and allocating appropriate funds as capital for library development [34].

The mosque (praying room) became the second choice of learning space after the library. In the past, the mosque's function was only a place of worship for Muslims. Now, the mosque's operations grow not only as a Muslim center but also as a religious tourism site, a place of learning, both for general science and Islamic spiritual knowledge [35]-[37]. The mosque is a symbol of religion and emphasizes the function of space as a public building. Many Muslims build mosques, such as public mosques, school mosques, office mosques, and campus mosques. The mosque also has impressive architecture and unique characteristics, such as carvings on the door, calligraphy on the walls, domes, and towers. The mosque area is commonly a quiet and pleasurable place to study because it has several rooms such as the main room, hall, auditorium, fishpond, porch, library, and green open space. Learning in mosque space can be done in groups or individually [38]-[40].

The preference for learning space selection in addition to the library and mosque is a multimedia laboratory. A laboratory is a place commonly used for practicum. The laboratories available at various schools consist of multimedia, science (biology, physics, chemistry), and history laboratories. There are laboratory support tools according to the type of laboratory and rooms design that support practical learning. Learning in a laboratory requires teachers who are experts in their fields. Without competent teachers, compatible facilities will not be maximally utilized. Meanwhile, inadequate facilities also inhibit the implementation of learning [41].

The purpose of the implementation of laboratory learning is to gain personal experience, not just theory [42]. Also, computer laboratories tend to provide space and time to practice student skills that are sometimes not under the curriculum. Technology that can visualize invisible objects into visible objects, visualize moving objects, and display various other features, technological developments are increasingly 
sophisticated, making students explore easily through his technology for literacy without going to a computer laboratory [43].

Every student has the opportunity to study in a good school environment. Every individual also needs a learning space designed for learning effectiveness [44], [45]. Utilization of learning space in schools can be done as schools in Melbourne create a "holding environment" school design by utilizing botanical gardens and green spaces. In addition, learning space can also be done in forest adventure [46], garden [47] and museum [48]. Indoor learning needs to have fun classroom design concepts. According to Prasetya [49], it covers at least four categories of elements forming a study room: 1) element forming space, including the color selection of wall paint, bedding/carpet if needed, and ceiling; 2) the aesthetic element of space, for example by putting up photos of the president and vice president and the state symbol, mounting works if for elementary school children, photographs of children, pictures/posters that support the theme of learning, school regulation, and Al Qur'an verses; 3) furniture material elements, such as chair pieces and their appropriate size, the shape of tables, paint tables and chairs; and 4) arrangement of furniture that supports interpersonal communication.

Based on the description above, it is clear that every place that has the potential to be a choice of students to learn has criteria: comfortable physical environment (with complete facilities and as needed); adequate lighting conditions and air ventilation; beautiful and calm scenery, to form a learning atmosphere that is quiet, pleasurable, and not boring. Besides, there is a need for competent, creative, and innovative assistant teachers because, without appropriate skills, teachers will have difficulty managing classroom management with essential outdoor learning. Alterator and Deed [50] research found that teachers need the ability to adapt to learning in open classrooms for those who are still 'new' and need the capacity of intrapersonal and interpersonal knowledge and skills to be able to maximize learning.

\section{CONCLUSION}

The most dominant school space chosen by students in elementary, junior high school and senior high schools in Yogyakarta, Indonesia, to study in schools include: libraries, mosques, and multimedia laboratories. The least preferred place is canteens, schoolyards, and halls. Reasons for choosing the learning space include thermal comfort, completeness of supporting facilities, acoustic comfort, and diversity of facilities. Other not so prominent reasons include learning productivity, site and building visual quality, safety controls, and psychological comfort. There are differences in preference for students' school space selection, based on: 1) School levels, preferences for thermal comfort and acoustic comfort tend to be directly proportional to increasing levels, while choices for completeness of facilities and diversity of supporting facilities tend to be inversely proportional; 2) Based on the school, there is one school that shows differences in preferences that dominate the diversity of activities, followed by the completeness of supporting facilities and thermal comfort; 3) Based on the school location zone (eastern, central, and western region of Yogyakarta, Indonesia), the preference for the visual quality of the site and buildings as well as the freedom of movement space is higher in western region schools, while in the central area, the preference for completeness of supporting facilities is higher than the other two regions.

\section{REFERENCES}

[1] S. Cheryan, S. A. Ziegler, V. C. Plaut, and A. N. Meltzoff, "Designing classrooms to maximize student achievement," Behav. Brain Sci., vol. 1, no. 1, pp. 4-12, 2014, doi: 10.1177/2372732214548677.

[2] M. L. Rands and A. M. Gansemer-Topf, "The room itself is active: How classroom design impacts student engagement," J. Learn. Spaces, vol. 6, no. 1, pp. 26-33, 2017.

[3] American Architectural Foundation, "Design for learning forum: School design and student learning in the 21st century," A report of findings, America, 2006.

[4] S. Syamsudduha and M. Rapi, "The use of the school environment as a learning resource in improving biology learning outcomes," Lentera Pendidik., vol. 15, no. 1, pp. 18-31, 2012.

[5] G. Yıldırım and G. Ö. Akamca, "The effect of outdoor learning activities on the development of preschool children," South African J. Educ., vol. 37, no. 2, pp. 1-10, 2017, doi: 10.15700/saje.v37n2a1378.

[6] A. Cooper, "Nature and the outdoor learning environment: The forgotten resource in early childhood education," Int. J. Early Child. Environ. Educ., vol. 3, no. 1, pp. 85-97, 2015.

[7] Sofnidar, Kamid, and K. Anwar, "The syntax design of outdoor learning model based on mathematics modeling," (in Bahasa), Edumatica, vol. 07, no. 2, pp. 1-10, 2017, doi: 10.22437/edumatica.v7i02.4211.

[8] H. Ozgan and M. Toprak, "Classroom effects on the effectiveness of a school," J. Educ. Instr. Stud. World, vol. 2, no. 2, pp. 102-109, 2012.

[9] K. Widiastuti, M. J. Susilo, and H. S. Nurfinaputri, "How classroom design impacts for student learning comfort: Architect perspective on designing classess," International Journal of Evaluation and Research in Education (IJERE), vol. 9, no. 3, pp. 1-9, 2020, doi: 10.11591/ijere.v9i3.20566. 
[10] Kamus Besar Bahasa Indonesia (KBBI), “Indonesian Dictionary,” 2019. [Online]. Available: https://kbbi.web.id/sekolah.html (accessed Feb 6, 2020).

[11] Minister of Education and Culture of the Republic of Indonesia. Regulation of the Minister of Education and Culture of Republic of Indonesia Number 19, the Smart Indonesia Program, 2016, pp. 1-9.

[12] M. G. Ariani and F. Mirdad, "The effect of school design on student performance," Int. Educ. Stud., vol. 9, no. 1, pp. 175-181, 2016, doi: 10.5539/ies.v9n1p175.

[13] C. K. Tanner, "Effects of school design on student outcomes," J. Educ. Adm., vol. 47, no. 3, pp. 381-399, 2009, doi: 10.1108/09578230910955809.

[14] S. M. Hughes, "The relationship between school design variables and student achievement in a large urban Texas school district," Dissertation, Baylor University, 2005. [Online]. Available: http://hdl.handle.net/2104/3012.

[15] K. Wall, J. Dockrell, and N. Peacey, "The built environment of the primary school; impacts on pupil learning and attainment and staff and pupil wellbeing," Research Survey 6/1, 2008.

[16] S. L. H. P. Setyawan and S. I. A. Dwiningrum, "Optimizing outdoor learning facilities in elementary school in indonesia: A preliminary study case study: SD Muhammadiyah Sapen Yogyakarta," in The 1st PGSD UST International Conference on Education, 2018, vol. 1, pp. 147-152.

[17] E. Zarghami and D. Fatourechi, "Impact of sustainable school design on primary school children's mental health and well-being," Int'l J. Adv. Agric. Environ. Engg, vol. 2, no. 1, pp. 31-38, 2015.

[18] C. Becker, G. Lauterbach, S. Spengler, U. Dettweiler, and F. Mess, "Effects of regular classes in outdoor education settings: A systematic review on students' learning, social and health dimensions," Int. J. Environ. Res. Public Health, vol. 14, no. 485, pp. 1-20, 2017, doi: 10.3390/ijerph14050485.

[19] J. Furlong, "Habits in habitats: School architecture and teachers' interactions with space in Manchester and Copenhagen," 4CITIES Master's Thesis, Université Libre de Bruxelles, 2015.

[20] K. E. Kariippanon, D. P. Cliff, S. J. Lancaster, A. D. Okely, and A. Parrish, "Flexible learning spaces facilitate interaction, collaboration and behavioural engagement in secondary school," PLoS One, vol. 14, no. 10, pp. 1-13, 2019.

[21] N. Ibrahim, N. H. Fadzil, and M. Saruwono, "Learning outside classrooms on campus ground : Malaysia," Asian J. Environ. Stud., vol. 4, no. 13, pp. 97-109, 2013, doi: 10.21834/ajbes.v3i9.68.

[22] D. Bannister, Guidelines on exploring and adapting learning spaced in schools. Belgia: European Schoolnet (EUN Partnership AISBL), 2017

[23] A. E. Sejati, Sumarmi, and I. N. Ruja, "The effect of outdoor study learning methods on the ability to write high school geography scientific papers," (in Bahasa), J. Pendidik. Teor. Penelitian, dan Pengemb., vol. 1, no. 2, pp. 80-86, 2016.

[24] V. J. Granito and M. E. Santana, "Psychology of learning spaces: Impact on teaching and learning," J. Learn. Spaces, vol. 5, no. 1, pp. 1-8, 2016.

[25] Minister of National Education of the Republic of Indonesia. Regulation of the Minister of National Education of the Republic of Indonesia Number 24, 2007, pp. 1-67.

[26] D. Harrop and B. Turpin, "A study exploring learners' informal learning space behaviors, attitudes, and preferences," New Rev. Acad. Librariansh., vol. 19, no. 1, pp. 58-77, 2013, doi: 10.1080/13614533.2013.740961.

[27] C. Damşa, M. Nerland, and Z. E. Andreadakis, "An ecological perspective on learner-constructed learning spaces," Br. J. Educ. Technol., vol. 50, no. 5, pp. 2075-2089, 2019, doi: 10.1111/bjet.12855.

[28] J. W. Creswell, Research Design Qualitative, Quantitative, And Mixed Methods Approaches, 3rd ed. California: SAGE Publication, 2008.

[29] L. Groat and D. Wang, Architectural Research Methods. New York: John Wiley \& Sons Inc, 2002.

[30] J. W. Creswell, Qualitative inquiry and research design: Choosing among five approach, 2nd ed. SAGE Publication, Inc., 1997.

[31] I. Muslikah, "Student's preferences in junior high school library services in Yogyakarta," (in Bahasa), Thesis, Yogyakarta State University, 2016.

[32] K. I. Murdawandari, "Using libraries on learning in high school 1 Bantul," (in Bahasa), Thesis, Yogyakarta State University, 2015. [Online]. Available: http://eprints.uny.ac.id/28844.

[33] D. Yantiningsih and Santoso, "Creating a library as a learning medium that is calm and comfortable (study in the holy stain library)," J. Perpust., vol. 3, no. 1, pp. 111-124, 2015.

[34] State Constitution of the Republic of Indonesia. Law Number 43 About Libraries. Jakarta, 2007.

[35] M. P. Mateo, "The mosque as an educational space: Muslim women and religious authority in 21 st-century spain," Religions, vol. 10, no. 222, pp. 1-12, 2019, doi: 10.3390/rel10030222.

[36] S. M. Adi and C. Puspitasari, "Mosque as a model of learning principles of sustainable architecture," J. Islam. Archit., vol. 4, no. 1, pp. 33-36, 2016.

[37] Z. Salah, Education in islam: The role of the mosque. United Kingdom: FSCT Limited, 2003

[38] N. M. B. Batri, "The development of mosque madrasah education system in Singapore," Salam J. Study Masy. Islam, vol. 15, no. 2, pp. 291-301, 2012.

[39] Y. Purwanto, A. Sarbini, J. Abdullah, and A. Qadafi, "Salman mosque as a center of Islamic da'wah and spiritual laboratory for campus community," Ilmu Dakwah Acad. J. Homilet. Stud., vol. 13, no. 1, pp. 1-24, 2019, doi: 10.15575/idajhs.v12i1.5839.

[40] A. Suprapti and D. Iswanto, "Mapping the socio-religious spaces of a kampong: A case of Kauman Semarang," IOP Conf. Ser. Earth Environ. Sci., vol. 213, no. 1, pp. 1-9, 2018, doi: 10.1088/1755-1315/213/1/012048.

[41] R. B. Pareek, "An assessment of availability and utilization of laboratory facilities for teaching science at secondary level,” Sci. Educ. Int., vol. 30, no. 1, pp. 75-81, 2019, doi: 10.33828/sei.v30.i1.9. 
[42] T. Isozaki, "Laboratory work as a teaching method: A historical case study of the institutionalization of laboratory science in japan," Espac. Tiempo y Educ., vol. 4, no. 2, pp. 101-120, 2017, doi: 10.14516/ete.177.

[43] J. Bernhard, "What matters for students' learning in the laboratory? Do not neglect the role of experimental equipment!" Instr. Sci., vol. 46, no. 6, pp. 819-846, 2018, doi: 10.1007/s11251-018-9469-x.

[44] N. Zainuddin, R. M. Idrus, and A. F. M. Jamal, "Designing learning spaces for effective learning," Maldives Natl. J. Res., vol. 6, no. 1, pp. 7-18, 2018.

[45] N. M. Ibrahim, M. M. Osman, S. Bachok, and M. Z. Mohamed, "Assessment on the condition of school facilities: Case study of the selected public schools in gombak district," Procedia - Soc. Behav. Sci., vol. 222, pp. 228-234, 2016, doi: 10.1016/j.sbspro.2016.05.151.

[46] A. Gambino, J. Davis, and N. Rowntree, "Young children learning for the environment: Researching a forest adventure," Aust. J. Environ. Educ., vol. 25, pp. 83-94, 2009, doi: 10.1017/s0814062600000422.

[47] J. McVittie, R. Datta, J. Kayira, and V. Anderson, "Relationality and decolonisation in children and youth garden spaces," Aust. J. Environ. Educ., vol. 35, no. 2, pp. 93-109, 2019, doi: 10.1017/aee.2019.7.

[48] İ. N. Altintas and Ç. K. Yenigül, "Active learning education in museum," International Journal of Evaluation and Research in Education (IJERE), vol. 9, no. 1, pp. 120-128, 2020, doi: 10.11591/ijere.v9i1.20380.

[49] N. Prasetya, "Study of the interior aspects of the study and play spaces in kindergartens in Surakarta," (in Bahasa), Dimens. Inter., vol. 10, no. 1, pp. 23-32, 2012, doi: 10.9744/interior.10.1.23-32.

[50] S. Alterator and C. Deed, "Teacher adaptation to open learning spaces," Issues Educ. Res., vol. 23, no. 3, pp. 315-330, 2013. 